\title{
Logistic regression analysis of financial literacy implications for retirement planning in Croatia
}

\author{
Dajana Barbićc ${ }^{1, \dagger}$, Irena Palić ${ }^{1}$ and Vlasta Bahovec ${ }^{1}$ \\ ${ }^{1}$ Department of Statistics, Faculty of Economics and Business, University of Zagreb, Trg \\ J.F. Kennedy 6, 10000 Zagreb, Croatia \\ E-mail: $\langle\{$ dbarbic, ipalic, vbahovec $\} @ e f z g . h r\rangle$
}

\begin{abstract}
The relationship between financial literacy and financial behavior is important, as individuals are increasingly being asked to take responsibility for their financial wellbeing, especially their retirement. Analyzing of individual savings and attitudes towards retirement planning is important, as these types of investments are a way of preserving security during years of financial vulnerability. Research indicates that individuals who do not save adequately for their retirement, generally have a relatively low level of financial literacy.

This research investigates the relationship between financial literacy and retirement planning in Croatia. To analyze the relationship between financial literacy and planning for retirement, maximum likelihood logistic regression analysis was used. The paper shows that those who answer financial literacy questions correctly are more likely to have a positive attitude towards retirement planning and are more likely to save for retirement, ensuring them of higher levels of financial security in retirement. The Goodness-of-Fit evaluation for the estimated logit model was performed using the Andrews and HosmerLemeshow Tests.
\end{abstract}

Keywords: financial literacy, maximum likelihood estimation, logistic regression analysis, retirement planning, saving for retirement, survey research

Received: October 15, 2016; accepted: December 14, 2016; available online: December 30, 2016

DOI: $10.17535 /$ crorr.2016.0022

\section{Introduction}

Retirement schemes are becoming increasingly complex. Due to increasing life expectancy, growing percentage of an aging population, a declining percentage of young people and low fertility rate, there has been a serious deterioration in the dependency ratio [2]. In August 2016, the dependency ratio in Croatia was 1:1.22 indicating that 1 retiree is financed by 1.22 employees. Retirement is quite expensive. It has been estimated that individuals in retirement require approxima-

$\dagger$ Corresponding author 
tely $70 \%$ of their current income to cover their living costs, while in all likelihood, they will get less than $50 \%$ of their income [2]. Therefore, the public retirement scheme can no longer guarantee adequate and sufficient pensions for future retirees.

It is becoming evident that new retirees will not be able to rely on the intergenerational solidarity system. Therefore, the standard of living of new retirees will primarily depend on various private savings and private investments. To be able to use financial products and services and invest money wisely, individuals need to be financially literate. They need to have at least basic financial knowledge and skills and be aware of the possible risks and threats connected with their financial choices.

The purpose of this paper is threefold. Firstly, the objective is to provide an overview of financial and retirement literacy in Croatia. Secondly, the relationship between financial literacy and attitudes towards retirement planning and saving for retirement will be analyzed using logistic regression analysis. Thirdly, this paper should contribute to the economic and educational policy in developing enhanced financial and retirement literacy programs and campaigns.

\section{The importance of financial literacy for retirement planning}

The retirement system in Croatia is composed of three pillars. The First two pillars are obligatory and are financed through contributions, while the third pillar is voluntary and represents individual capitalized savings.

The pensions of Croatian retirees are generally very low and the current retirement system is unsustainable in the long run. Accordingly, it is very likely that future pensions acquired from the first and second pillar from today's employees will be rather low as well. Besides the previously mentioned problems of the Croatian retirement system, the period that individuals spend in retirement, their living costs increase further due to greater life expectancy.

The system is becoming weaker every day and individuals are becoming even more responsible with their retirement and their savings. Although the first and second pillars are the financial source of retirement for most of the current retirees, in the future, they will remain only at a minimal or level for their social protection and retirees will be mainly personally responsible for their retirement savings. Making informed financial decisions means that individuals possess financial knowledge and skills. Financial literacy is a combination of financial knowledge and skills and is aimed at increasing the level of responsibility in using financial products and services and taking risks in making financial decisions [7].

Research in [1], [4], [5], [7], [8], [9], [13], [16] and [22] has demonstrated strong links between financial knowledge and financial behavior. In their paper [16], they found that many respondents lack crucial knowledge in financial concepts and fail 
to plan properly for retirement, even when retirement is close. Their findings suggest that financial illiteracy correlates with lower wealth accumulation at retirement. Another study [17] concluded that financial knowledge and retirement planning are interrelated. Studies investigating financial literacy in Croatia suggest that Croatians have a relatively low level of financial literacy (see [2], [6], [7] and [23]). The results of the study obtained by [20] show that among active population in Croatia, $54 \%$ of respondents are retirement illiterate. When compared with financially and retirement literate respondents, this group statistically has a significant lower personal income, lower level of general education and were more often unemployed or employed for only a fixed period of time.

According to [6], the lowest level of financial literacy in Croatia was found to be among the elder respondents ( $>70$ years). Their findings indicated that $74 \%$ of all respondents expect to receive their retirement from the first pillar based on intergenerational solidarity; $55 \%$ of respondents expect to receive retirement from the second pillar and only $17 \%$ respondents expect retirement from the third voluntary pillar.

Most of the research shows that individuals are insufficiently focused on retirement planning [20]. Many Croatians stated that they are uncertain whether they have made proper plans for retirement [6]. An insufficient level of financial awareness may lead to very low standard of living for future retirees. The greater life expectancy and low level of private retirement savings will eventually result in greater poverty of the elderly. Given the evidence on widespread financial illiteracy and limited retirement knowledge, obviously, there is an interest for policies to address the issue of financial literacy and financial education affecting attitudes towards retirement planning and savings behavior.

\section{Data and model description}

\subsection{Data}

The sample in this paper comprises people living in Croatia, aged 20-79 years. The questionnaire was completed by a judgmental sample of 30 respondents living in Zagreb. In the next phase, the questionnaire was pretested on 100 respondents living in Croatia. Feedback from both samples was used in finalizing the questionnaire which was then completed by respondents in July 2014. It was administered in the form of a telephone survey using a base of randomly selected fixed and mobile phone numbers. A total of 494 respondents were surveyed with this paper relying on a sample size of 451 respondents, less due to incomplete data.

The questionnaire was devised according to [16] the basic financial literacy scale and included a set of questions on financial concepts and calculations (inflation, 
interest rate compounding, risk diversification, percentage calculation etc.). Prior to applying the questionnaire to the final sample, the financial literacy scale was tested for validity and reliability [12]. To test the validity of financial literacy scale, exploratory factor analysis was used. Exploratory factor analysis is a statistical method used to test the connection within a group of observed variables, measured in terms of items or questions [3]. In literature exploring similar matters, there is no consensus regarding the percentage of variance that should explain whether a certain factor is sufficient. Some studies cite that it should be $75-90 \%$, but many authors state a variance exceeding $50 \%$ is sufficient [3]. Using exploratory factor analysis, insufficiently informative variables are excluded from further analysis. The following relative criteria are used: (1) Kaiser criteria; (2) Cattell diagram; (3) Percentage of explained variance; (4) Theoretical meaningfulness [19]. One factor that satisfies the mentioned criteria and holds information on financial literacy of Croatian financial consumers is retained. Table 1 and Table 2 show the results of exploratory factor analysis.

\begin{tabular}{|l|r|c|r|r|r|r|}
\hline \multirow{2}{*}{$\begin{array}{l}\text { Compone } \\
\text { nt }\end{array}$} & \multicolumn{3}{|c|}{ Initial Eigenvalues } & \multicolumn{3}{|c|}{$\begin{array}{c}\text { Extraction Sums of Squared } \\
\text { Loadings }\end{array}$} \\
\cline { 2 - 7 } & $\begin{array}{c}\text { Tot } \\
\text { al }\end{array}$ & $\begin{array}{c}\text { \% of } \\
\text { Varian } \\
\text { ce }\end{array}$ & $\begin{array}{c}\text { Cumulati } \\
\text { ve \% }\end{array}$ & $\begin{array}{c}\text { Tot } \\
\text { al }\end{array}$ & $\begin{array}{c}\% \text { of } \\
\text { Varian } \\
\text { ce }\end{array}$ & $\begin{array}{c}\text { Cumulati } \\
\text { ve } \%\end{array}$ \\
\hline 1 & $\begin{array}{r}1.54 \\
1\end{array}$ & 51.355 & 51.355 & $\begin{array}{r}1.54 \\
1\end{array}$ & 51.355 & 51.355 \\
\hline 2 & .776 & 25.855 & 77.210 & & & \\
\hline 3 & .684 & 22.790 & 100.000 & & & \\
\hline
\end{tabular}

Table 1: Total variance explained (SPSS) [authors]

From Table 1 it is obvious that the eigenvalue for the first component is quite larger than the eigenvalue for the next component (1.541 versus 0.776). Additionally, the first component accounts for $51.355 \%$ of the total variance. This suggests that the scale items are unidimensional.

\begin{tabular}{|l|l|}
\hline Inflation & 0.692 \\
\hline Interest & 0.754 \\
\hline Diversification & 0.702 \\
\hline
\end{tabular}

Table 2: Component matrix (SPSS) [authors]

Furthermore, Table 3 shows component loadings, which are the correlations between the variable and the component. All three items have factor loadings of 0.6 and above. After exploratory factor analysis, the reliability analysis of the measuring instrument and the latent variables is conducted. Cronbach alpha is 
often used to test the internal consistency of the measurement scales and to verify the reliability of the measuring instrument. The Cronbach alpha coefficient for the financial literacy scale is 0.739 suggesting that the items have a relatively high internal consistency.

\begin{tabular}{|l|l|}
\hline \multicolumn{1}{|c|}{ Financial literacy } & \multicolumn{1}{|c|}{ Items } \\
\hline Interest rate & $\begin{array}{l}\text { Imagine that the interest rate on your } \\
\text { savings was 1\% per year and inflation } \\
\text { was 2\% per year. After 1 year, you will } \\
\text { have more than today. }\end{array}$ \\
\hline Inflation & $\begin{array}{l}\text { Suppose you had 100 HRK on your } \\
\text { account and the interest rate is 2\% per } \\
\text { year. After 5 years, you will have } \\
\text { exactly 102 HRK. }\end{array}$ \\
\hline Risk diversification & $\begin{array}{l}\text { By investing money in securities of } \\
\text { various joint stock companies and } \\
\text { other legal entities, the average } \\
\text { investor increases his risk of loss. }\end{array}$ \\
\hline
\end{tabular}

Table 3: Items used to define basic financial literacy [authors]

Based on previously described procedures, a set of three questions (to measure basic level of financial literacy) was designed. Table 3 reports the precise wording of the basic financial literacy questions that analyze numerical skills and understanding of basic concepts such as interest rates, inflation, and risk diversification. The respondents were asked to choose between two options; correct and incorrect. Figure 1 summarizes the responses to the basic financial literacy questions. 


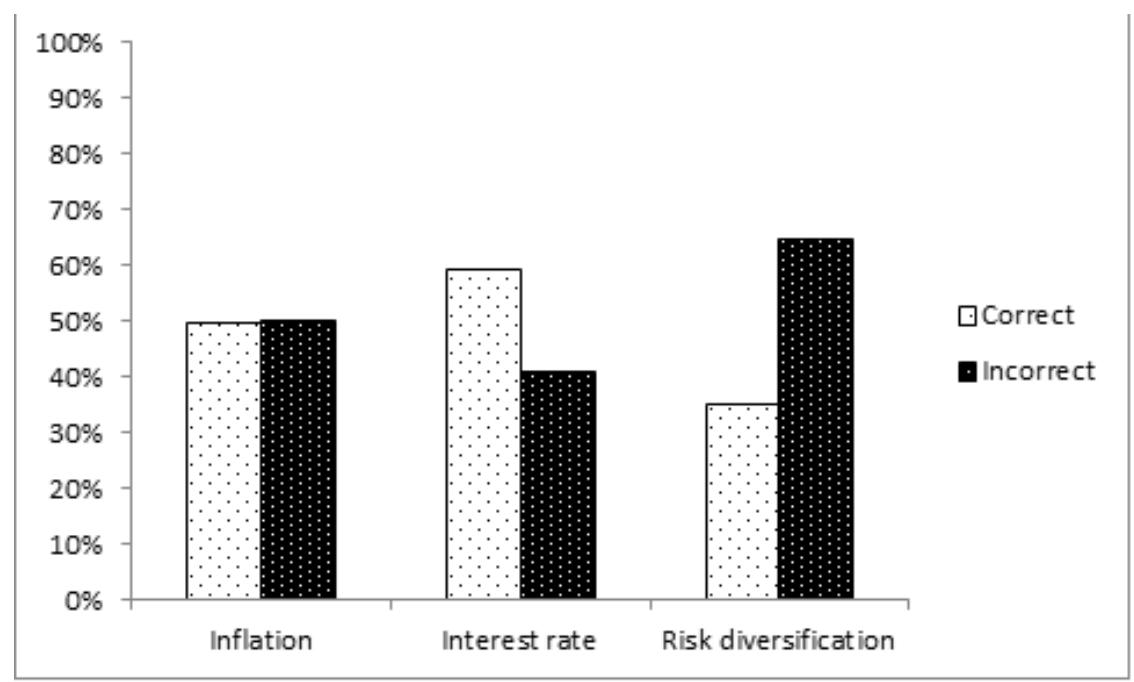

Figure 1: Responses to the basic financial literacy questions [authors]

The respondents demonstrated a rather low level of basic financial literacy. Most of the respondents $(59.2 \%)$ correctly answered to the interest rate question. However, $50.11 \%$ of respondents answered the inflation question incorrectly while only $35.03 \%$ respondents gave the correct answer to the risk diversification question.

In the next step, the level of retirement planning is investigated based on: (1) Positive attitudes towards retirement planning, and (2) Private retirement saving/investment plan.

\begin{tabular}{|l|l|}
\hline \multicolumn{1}{|c|}{ Planning for the retirement } & \multicolumn{1}{c|}{ Statements } \\
\hline $\begin{array}{l}\text { Positive attitude towards retirement } \\
\text { planning }\end{array}$ & $\begin{array}{l}\text { I think it is very important to have a } \\
\text { retirement plan. }\end{array}$ \\
\hline $\begin{array}{l}\text { Private retirement saving/investment } \\
\text { plan }\end{array}$ & $\begin{array}{l}\text { I have private retirement } \\
\text { savings/investments (third pillar). }\end{array}$ \\
\hline
\end{tabular}

Table 4: Planning for the retirement [authors] 


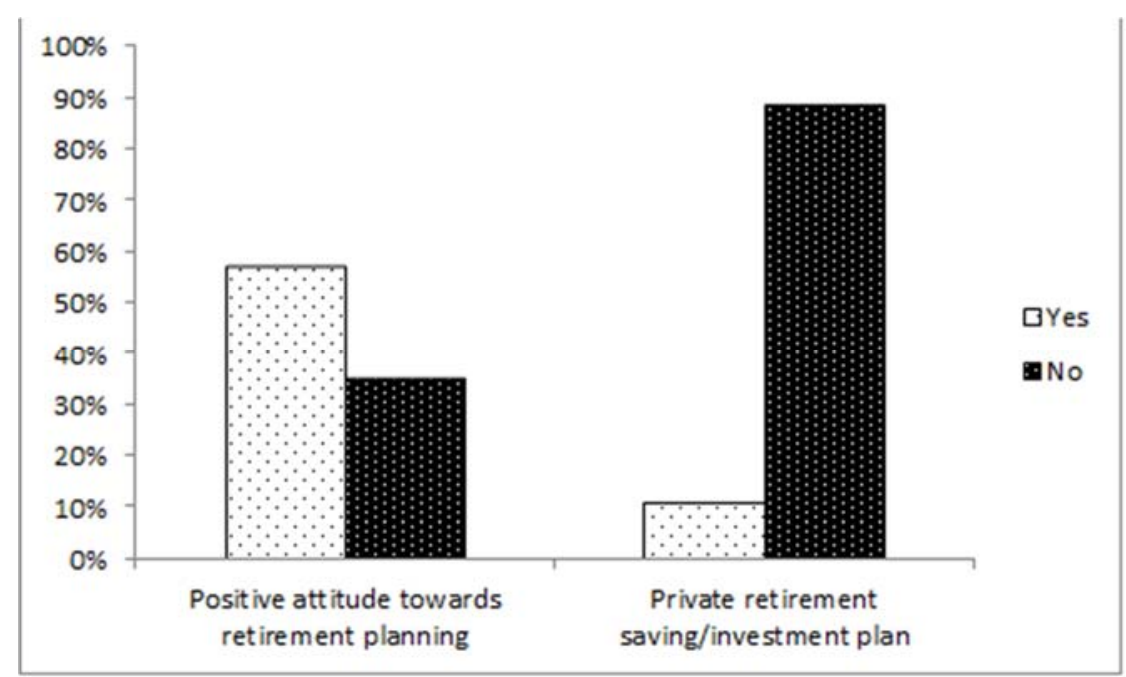

Figure 2: Planning for retirement [authors]

Results of our study show that $57.43 \%$ of respondents have positive attitude towards retirement planning. However, only $11.31 \%$ of it involves private retirement investments.

\subsection{The logistic regression model}

Logistic regression refers to a special form of regression where the dependent variable is a dichotomous variable. The form of the logistic regression variate is similar to the variate in multiple regressions. The variate represents a single multivariate relationship with regression-like coefficients indicating the relative impact of each predictor variable. In relation to discriminant multivariate analysis, logistic regression has the advantage of being less affected when basic assumptions, particularly normality of the variables, are not met [12].

Regardless of the similarities between linear and logistic regression, linear regression cannot be applied directly when the outcome variable is categorical. The reason is that one of the linear regression assumptions is the linear relationship between variables and when the outcome variable is categorical, this assumption is violated. One way to resolve that is to express non-linear relationship in a linear way. The logistic regression equation expresses the linear regression equation in logarithmic terms and this overcomes the problem of violating linearity assumption [10]. The logistic model is estimated using the maximum likelihood estimation (ML) method. The ML estimator finds the maximum likelihood parameter estimates by maximizing the likelihood function, which expresses the probability of the observed data as a function of the unknown 
parameters. The ML procedure is used in an iterative manner, to find the most likely estimates for parameters ([7] and [18]).

The probability model is a regression (see [11]):

$$
E[y \mid x]=0\left[1-F\left(x^{\prime} \beta\right)\right]+1 F\left(x^{\prime} \beta\right)=F\left(x^{\prime} \beta\right)
$$

The logistic distribution is given by (1):

$$
\operatorname{Prob}(Y=1 \mid x)=\frac{e^{x^{\prime} \beta}}{1+e^{x^{\prime} \beta}}=\Lambda\left(x^{\prime} \beta\right)
$$

where $\Lambda($.$) indicates the logistic cumulative distribution function which has been$ used in many applications, partly because of its mathematical convenience. The logistic distribution is similar to the normal except in the tails, which are considerably heavier [11].

The logistic regression model predicts the probability of an event occurring for a given person based on observations as to whether or not the event occurred for that person. The observed and predicted values are used to assess the fit of the model and the measure which is used is log-likelihood denoted by $L L$ :

$$
L L=\sum_{i=1}^{N}\left[Y_{i} \ln \left(P\left(Y_{i}\right)\right)+\left(1-Y_{i}\right) \ln \left(1-P\left(Y_{i}\right)\right)\right]
$$

The log-likelihood is based on summing the probabilities associated with predicted and actual outcomes [21].

In logistic regression estimation, the value of the model chi-square is defined by following equation [10]:

$$
\begin{aligned}
& \chi^{2}=2[L L(\text { new })-L L(\text { baseline })] \\
& \left(d f=k_{\text {new }}-k_{\text {baseline }}\right)
\end{aligned}
$$

Hence, the baseline model log-likelihood (the model where only constant is included) is subtracted from the estimated model log likelihood.

Moreover, regarding $\mathrm{R}^{2}$, there are three common measures that are similar in interpretation to $\mathrm{R}^{2}$ in linear regression: Hosmer and Lemeshow's $R_{H L}^{2}$, Cox and Snell's $R_{C S}^{2}$ and Nagelkerke's $R_{N}^{2}$ : Hosmer and Lemeshow's $R_{H L}^{2}$, Cox and Snell's $R_{C S}^{2}$ are included in the output of SPSS software and detailed computation is explained in Field (2009). Although they are different in computation, they are conceptually similar and point to the substantive significance of the model. $R_{H L}^{2}$ is calclulated by dividing the model chi-square (based on the log-likelihood) by the original log-likelihood, i.e. the log-likelihood of the model before any predictors were entered [10]:

$$
R_{H L}^{2}=\frac{-2 L L(\text { model })}{-2 L L(\text { baseline })}
$$


Moreover, the Hosmer-Lemeshow test is used to analyze the goodness of fit for logistic regression models. The test assesses whether or not the observed event rates match expected event rates in subgroups of the model population. The significance of the test statistic points to the poor model fit (for detailed explanation see [14]). The final indicator which is often analyzed in logistic regression estimation is the odds ratio. It can be interpreted in terms of the change in odds. A value greater than one, indicates that as the predictor increases, the odds of the outcome occurring also increase, and vice versa.

\section{The results of the model estimation}

After extracting one factor, logistic regression analysis is performed to assess the impact of financial literacy on attitudes towards retirement planning and on investing for retirement as the third retirement pillar. Two logistic regression models were estimated. The predictor variable in both models is financial literacy. The response variable in Model 1 is attitude towards retirement planning, while the response variable in Model 2 is investment in the third retirement pillar. Table 5 shows the result of logistic regression estimation for Model 1 . The coefficient $\hat{\beta}_{\text {Model } 1}$ represents the logit of the attitude towards retirement planning associated with one-unit change in financial literacy. The crucial statistic is a Wald statistic that has chi-square distribution and equals 6.616 with the corresponding p-value equal 0.01. It indicates whether the estimated coefficient is statistically different from zero. The chi-square test statistic equals to the $-2 L L$ of the model in which financial literacy is included minus the value $-2 L L$ of the model which has only constant included. Hence, the chi-square test statistic shows the effect of the removal of financial literacy from the model. Regarding the significance of the chi square, it is significant at $1 \%$ which tells us that removing financial literacy would have a significant effect on the predictive ability of the model. In other words, removing it is not recommended as financial literacy is significant at a $1 \%$ significance in explaining the attitude towards retirement planning. Therefore, financially literacy is a significant predictor as to whether the person will have a positive attitude towards retirement planning. Moreover, the odds ratio refers to the ratio of odds after a unit change in the predictor over the original odds and equals 1.280. The odds ratio is interpreted in terms of change in odds. Therefore, the odds of a person who is financially literate having a positive attitude towards retirement planning is 1.28 times higher than that of a person who is not financially literate. The population value of the odds ratio is between 1.059 and 1.547 with a $95 \%$ confidence. 


\begin{tabular}{|l|c|c|c|c|c|}
\hline & $\hat{\beta}_{\text {Model 1 }}(\mathrm{SE})$ & $\mathrm{p}$-value & $\begin{array}{c}\text { Odds } \\
\text { ratio }\end{array}$ & $\begin{array}{c}\text { Lower } \\
95 \%\end{array}$ & Upper 95\% \\
\hline \hline Included \\
\hline \hline Constant & $0.304(0.096)$ & 0.011 & & & \\
\hline FL & $0.247(0.097)$ & 0.002 & 1.280 & 1.059 & 1.547 \\
\hline \hline Note: $R_{H L}^{2}=0.011, R_{C S}^{2}=0.015, R_{N}^{2}=0.02, \chi^{2}(1)=6.616, \mathrm{p}$-value $=0.01$ \\
\hline
\end{tabular}

Table 5: The logistic regression estimation results for Model 1

Table 6 shows the results of logistic regression estimation for Model 2. The coefficient $\hat{\beta}_{\text {Model } 2}$ refers to the logit of investing in third retirement pillar based on a one-unit change in financial literacy. The Wald statistic equals 5.038 and shows that financial literacy is significant at a $5 \%$ significance in explaining investments in the third retirement pillar. This indicates that the model is better at predicting whether someone will invest in the third pillar than before financial literacy is added. Therefore, financial literacy is a significant predictor as to whether the person will invest for retirement in the third retirement pillar. Moreover, the odds of a person who is financially literate investing into the third retirement pillar is 1.42 times higher than that of a person who is not financially literate. The population value of odds ratio is between 1.049 and 1.912 with a $95 \%$ confidence.

\begin{tabular}{|c|c|c|c|c|c|}
\hline & $\begin{array}{l}\hat{\beta}_{\text {Model } 2} \\
\text { (SE) }\end{array}$ & p-value & $\begin{array}{l}\text { Odds } \\
\text { ratio }\end{array}$ & Lower $95 \%$ & Upper $95 \%$ \\
\hline \multicolumn{6}{|l|}{ Included } \\
\hline Constant & $\begin{array}{l}-2.106 \\
(0.155)\end{array}$ & 0.023 & & & \\
\hline FL & $0.348(0.153)$ & 0.000 & 1.416 & 1.049 & 1.912 \\
\hline
\end{tabular}

Table 6: The logistic regression estimation results for Model 2

The values of Hosmer and Lemeshow's $R_{H L}^{2}$, Cox and Snell's $R_{C S}^{2}$ and Nagelkerke's $R_{N}^{2}$ for the estimated models are also shown in the Tables 5 and 6 . Although they are quite low, this is expected due to the fact that financial literacy is not to be expected as only factor affecting attitudes towards retirement planning. However, in this research the aim is to analyze whether the impact of financial literacy on attitude towards retirement planning and investments for retirement is significant, without including other factors. 
Moreover, the classification shows how well models predict group membership, because financial literacy is used to predict the outcome variables. Model 1 overall correctly classifies $55.7 \%$ of respondents, while Model 2 correctly classifies $88.7 \%$ of respondents. The Hosmer and Lemeshow test is also conducted for both models. The value of $\chi^{2}(6)$ equals 9.940 with corresponding p-value of 0.326 for Model 1. For Model $2, \chi^{2}(6)$ equals 12.437 with p-value equal to 0.053 . In both cases the conclusion is that the null hypothesis is not rejected at a $5 \%$ significance. If the p-value is low, the null hypothesis is rejected and the model lacks proper fit. Since both p-values are larger than 0.05 , this indicates the models should not be rejected.

\section{Conclusions}

Financial literacy and retirement planning habits among Croatians and the relationship between financial literacy and retirement planning are analyzed in this paper. The findings of the paper show that financial illiteracy is widespread and that the lack of basic financial literacy has important consequences for retirement planning, which points to policy implications. Furthermore, the results indicate that people generally have positive attitudes towards retirement planning, but only few of them actual have private retirement savings. This situation is primarily caused by an inadequate level of information that individuals have when it comes to the long-term sustainability of the Croatian retirement system. They are still not aware that their financial wellbeing in retirement will mainly depend on their own savings and investments.

The logistic regression analysis has shown that financial literacy is a significant predictor whether the person will invest for retirement in form of third retirement pillar and whether the person will have a positive attitude towards retirement planning. Individuals who possess basic financial literacy knowledge and skills will be more prone to having a positive attitude toward retirement planning and having private retirement investments. This suggests that financial knowledge and skills are very important for making financial and retirement decisions.

This study emphasized the role of basic financial literacy by effectively boosting retirement planning behavior among households. One of the reasons why this is important for individuals and households is evidence that many individuals enter retirement with very little or no wealth. This has profound implications not only on individual welfare but also for public policy, as low retirement savings means more poverty among the elderly and more individuals being dependent on state benefits. 


\section{Acknowledgement}

This work has been fully supported by the Croatian Science Foundation under the project STRENGTHS no 9402.

\section{References}

[1] Bahovec, V., Barbić, D., Palić, I. (2015). Testing the effects of financial literacy on debt behavior of financial consumers using multivariate analysis methods. Croatian Operational Research Review, 6 (2), 361-371.

[2] Barbić, D. (2016). Investigating Financial Literacy in Croatia, 2016 IEC \& 2016 ISEC Proceedings Venice, Italy, 287-1-287-7

[3] Beavers, A. S., Lounsbury, J. W., Richards, J. K., Huck, S. W., Skolits, G. J., Esquivel, S. L. (2013). Practical considerations for using exploratory factor analysis in educational research. Practical Assessment, Research \& Evaluation, 18 (6): 1-13.

[4] Bernheim, B. D., Garrett, D. M. (2003). The effects of financial education in the workplace: evidence from a survey of households. Journal of Public Economics, 87: 1487-1519.

[5] Bernheim, B. D., Garrett, D. M., Maki, D. (2001a). Education and saving: The long-term effects of high school financial curriculum mandates. Journal of Public Economics, 87 (7): 1487-1519.

[6] Croatian National Bank (2016) Mjerenje financijske pismenosti i financijske uključenosti u Hrvatskoj.

[7] Cvrlje, D. (2014). Linking the concept of financial literacy with the successfulness in managing personal finances. Doctoral thesis, Zagreb.

[8] Cvrlje, D., Bahovec, V., Palić, I. (2015a). Exploring the Effects of Financial Education: Analysis of Saving Behavior of Croatian Consumers. Economic and Social Development (ESD) Book of Proceedings, Jovancai Stakic, A., Kovsca, V., Bendekovic, J. (ur.)., 241-250.

[9] Cvrlje, D., Bahovec, V., Palić, I. (2015b). The analysis of the financial education impact on investment behavior in Croatia: Ordered logistic regression approach, Proceedings of the 13th International Symposium on Operational research / L. Zadnik Stirn, J.Žerovnik, M.Kljajić Borštar, S.Drobne (ur.)., 389-394.

[10] Field, A. (2009) Discovering statistics using SPSS. $3^{\text {rd }}$ ed. Sage Publications: Thousand Oaks.

[11] Greene, W. H. (2012). Econometric analysis. $7^{\text {th }}$ ed. Pearson Prentice Hall: Upper Saddle River.

[12] Hair, J. F., Black, W. C., Babin, B. J., Anderson, R. E. (2010). Multivariate Data Analysis: A Global Perspective. 7th ed. New Jersey: Pearson. 
[13] Hilgert, M. A., Hogarth, J. M., Beverly, S. G. (2003). Household Financial Management: The Connection between Knowledge and Behavior. Federal Reserve Bulletin, 309-322.

[14] Hosmer, D.W., Lemeshow, S. (2013). Applied Logistic Regression. New York: [15] Kennedy, P. (2008). A guide to Econometrics, 6th ed. Blackwell Publishing.

[16] Lusardi, A., Mitchell, O. (2009). How ordinary consumers make complex economic decisions: financial literacy and retirement readiness. NBER Working Paper, No. 15350.

[17] Lusardi, A.; Mitchell, O.S. (2011). Financial literacy and retirement planning in the Untited States, NBER Working paper series, 17108.

[18] Menard, S.W. (2002). Applied Logistic Regression analysis, 2nd ed. Thousand Oaks: Sage.

[19] Milošević, M. (2010.). Izrada mjernog instrumenta stresa na radnom mjestu bolničkih zdravstvenih djelatnika i procjena njegove uporabne vrijednosti (Development of workplace stress measurement instrument of hospital health staff and assessment of its usability). Doktorska disertacija, Zagreb.

[20] Škreblin Kirbiš, I., Tomić, I., Vehovec, M. (2011.). Mirovinska pismenost i štednja za treću životnu dob (Retirement literacy and savings for the third life age). Revija za socijalnu politiku, 18 (2): 127-148.

[21] Tabachnick, B.G., Fidell, L.S. (2007). Using Multivariate Statistics, 5th ed. Pearson, Allyn and Bacon, Boston

[22] Van Rooij, M. A.; Lusardi, A.; Alessie, R. (2008). Financial literacy, retirement planning, and household wealth. De Nederlandsche Bank, Amsterdam.

[23] Vehovec, M.; Rajh, E.; Škreblin Kirbiš, I. (2015). Financijska pismenost građana u Hrvatskoj (Financial literary of Croatian citizens). Privredna kretanja i ekonomska politika, 1(36): 53-75. 